\title{
Critique against Social Injustice in the Book of Amos: Its Relevance to Development in Nigeria
}

\author{
Ikenna L. Umeanolue \\ http://dx.doi./org/10.4314/ujah.v19i2.10
}

\section{Abstract}

In the Old Testament book of Amos, the basic message of prophet Amos stresses the divine demand for social justice and concern for the oppressed in $8^{\text {th }}$ century Israel. Many among Israel's wealthy members of the society at the time of Amos chose to be unjust and to treat the disadvantaged as they wished. Amos connects the injustice he sees around him to a society bent on wealth and prosperity while being forgetful of the true worship of God. As justice was denied in Amos' time, so also it is being denied in contemporary Nigerian society. The research examined some of the social injustices observable in Nigeria such as socio-economic injustice, socio-political injustice, socio-religious injustice and socio-judicial injustice. It is the conclusion of this paper that for a meaningful development in Nigerian society, Nigerians should learn to practise social justice as demanded in the book of Amos.

\section{Introduction}

The message of Amos as contained in his book stresses on social justice in $8^{\text {th }}$ century Israel. A distinctive feature of Israelite religion was the interconnection between the relationships to one's neighbour and to God as established by the covenant. The quality of one's relationship to God depended to some extent on how one related to fellow members of the covenant community. At the time of Amos, many among Israel's powerful had chosen to ignore this aspect of Israelite religion and to treat the disadvantaged as they 
wished. Wealthy landowners oppressed the less fortunate, taking over the land holdings of many impoverished Israelites. Ivory places were built, and businessmen became impatient with Sabbath restrictions. The rich were oppressive and corrupt; the courts were unjust; the righteous services were either a sham or consisted of idolatory. Superstition and immorality were the order of the day. Amos saw that such dreadful conditions could not bring God's blessings rather than judgement and punishment. The prophet expresses God's distress at the maltreatment of the less privileged people (Amos 2:7; 4:1; 5:7, 11, 24; 8:4-6).

Just like the society of northern Israel to which Amos delivered his message, in the contemporary Nigerian society, social injustice has been the order of the day. Social justice which was the subject matter of Amos' message is one major thing which Nigerians are lacking. This could be observed from various forms of social injustice prevalent in contemporary Nigerian society. This ugly trend hampers development in all sectors of Nigerian society. Considering the high level of religiosity in the country, these injustices have proved Nigeria as a religious society without sense of justice. Many Nigerians pretend to be religious while virtually a lot of injustice and immorality are being committed by the same people. Some of the Nigerian religious activities and prayers are like those of the Israelites of Amos' time. They are yet to make impact on our society. In the light of this one wonders the essence of religion in Nigeria.

This research aims at studying Amos' message of social justice in Israel and its relevance to societal development in contemporary Nigeria. It is also the purpose of this paper to examine the different forms of social injustices in contemporary Nigerian society. The injustices in the present day Nigeria are 
viewed in the context of the injustices that existed in the Northern Israel to which Amos delivered his message.

The word justice is a virtue that has been defined as rights and duties of people to each other. Hornby (2000) and AdrianVallance et al (2009) define justice as fairness in the way people are treated. According to Iwe (1985) "justice as an ethical concept with immense social significance implies the notion of fairness, fair deal, moral integrity and righteousness in the dealings of men with one another and in the affairs and transaction of social life" (p. 235). Injustice which is opposite of justice comprises man's inhumanity to man, unfair distribution of natural endowments and infringement of fundamental human rights. These triggered the radical teaching of Prophet Amos in Israel.

Social injustice on the other hand is the opposite of social justice. Social justice is primarily concerned with how society is organized, how health, power, privileges, rights and responsibilities are distributed to each strata of the society. Obiajulu (1996) defines social justice as "a more equitable distribution of the social resources and more equitable access to the various social institutions by all members of the society" (p.18). To Iwe (1985), "Social justice has its direct object as the common good of the members of the society. Social justice recognizes and assumes the fact that we are all members of the same human family" (p. 24). Ojiakor and Unachukwu (2001) are also of the view that:

Social justice means above all working to build a society that is intrinsically balanced, a society in which the structures are fair to everybody without exception. For instance, constructing a society in which the minorities, the homeless, women and the poor are not discriminated against either in law or in practice (p. 174). 
On the basis of the above definitions, social justice demands that each member and each sector of the society should contribute its own quota for the attainment of the common good of the whole. Social justice in this context is based on human rights and equality which social injustice does not guarantee.

\section{Amos and Critique against Social Injustice}

The book of Amos is one of the twelve shorter prophetic works of the Old Testament gathered into a collection known as the Book of the Twelve or the Minor Prophets. The book contains nine chapters and is divided as follows: Oracle against the nations (1-2); oracles against Israel (3-6); collection of visions about the end of Israel (7:1-9:10); promise of restoration (9:11-15). All that is known about Amos (the author) is found in the book which bears his name. Amos had lived at Tekoa, a small town in Judah near Bethlehem (Amos 1:1, 7:12). He introduces himself as neither a prophet nor a prophet's son, but a headsman and a dresser of sycamore trees called by God to prophesy to the people of Israel. Amos came from his farming work to be a prophet to the people of Israel. According to MacDonald (1990), "Amos ministered during the reigns of Uzziah in Judah (790-739 B.C.) and Jeroboam II in Israel (739- 753 B.C), an age of affluence, luxury, and moral laxity, especially in the Northern kingdom" (p. 1113). Because Amos came from the countryside, where everyone had to work had for a living, he was disgusted to see the wealth, the laziness and the unjust behaviour of some of the town dwellers in the Northern Kingdom of Israel. The subject matter of his message was social justice. He was a stern prophet of righteousness and uncompromising justice.

Much of the prophecy of Amos is directed at the heartlessness of wealthy merchants who ignore the plight of the 
poor, the lack of justice for the righteous, and the emptiness of religious ritual apart from true faith. In the words of Boadt (1884), "the basic message of Amos stresses God's moral rule over the entire world and the divine demands for justice and concern for the outcast or oppressed" (p. 316). He is a classical prophet concerned with the well being of the people and the purity of the faith. Emenike (2003) comments that the message of Amos was against social sins such as injustice, corruption, greed and false worship, which prevailed in surrounding nations especially in Israel. This is expressed in Amos 5:24 where Amos cautions the people to let justice roll down like waters, and righteousness like an ever flowing stream. This particular verse in the book of Amos captures the core message of this great writing prophet who truly believes that life-giving worship of God and social justice are inseparable.

The significance of the book of Amos lies in the fact that Amos has been universally acclaimed as the prophet of social justice. For him covenant loyalty to God can be shown only by being fair to the members of the covenant, who are considered as brothers and sisters. No wonder has become the source of inspiration for liberation theology and for anyone who is working to defend the rights of the poor and the marginalized against any sort of oppressors (Ceresko, 1992; Menezes, 2003). Amos exposes the utter meaninglessness of a cult that is formalistic. God is not a tribal or a national God who can be placated by sacrifice and incense. He condemns social injustices and demands moral uprightness of an individual, and concern for the rights of the neighbour. He brings to book anyone who tramples upon the rights of another whether it is a powerful nation or an individual.

God had promised to care for the Israelites and save them from their enemies if they would follow the way of life which he laid down for them. Thorogood (1992) says "This special 
relationship with God had given the people of Israel special opportunities for understanding what God is like and how people ought to serve him" (p. 12). But when Amos looked at his fellow Israelites, he saw the Israelites breaking their promise to God, and behaving as though the law which he had laid down for them did not exist (Amos 2.4). Amos preached the stern message that if the Israelites continued to behave in this way, then they would not expect to receive the great blessings which God had promised in his covenant with them (Exodus 34). Amos saw that the Kingdom of Israel was in no condition to resist attack by Assyria, and would be destroyed; yet he pleaded for a change of heart. He ends his message with a proclamation and restoration of hope for the people of Israel if they mend their ways (Amos 9:13-15).

\section{Social Injustice in Amos' Time and Contemporary Nigerian Society}

The situation of Amos' time in Israel is very much like that of Nigeria today. Comparing Nigeria with Israel in the time of Amos, one would observe that Nigeria has become a place where the land, money and wealth are shared among the nobles at the detriment of the poor. The poor suffer in the hands of the rich. Oppression has become the food of the populace. Since Nigeria gained independence in 1960, tribalism, nepotism, corruption, discrimination, rigging of elections and gross injustice have dominated the economic, political, judicial, cultural, religious and ethnic lives and minds of many Nigerians. In other words, in contemporary Nigeria, one is amazed by various forms of social injustice such as (i) socio-economic injustice, (ii) socio-political injustices, (iii) socio-religious injustice, and (iv) socio-judicial injustice. As justice was denied at the time of Amos, so it is also 
being denied in the contemporary Nigerian society. This is evident as discussed below.

\section{i. Socio-Economic Injustice}

The socio-economic situation of Amos time in Israel is very much like that of Nigeria today. Just like in Amos' time, the signs of economic prosperity in Nigeria could be seen in so many things. Nigeria is naturally blessed with a lot of mineral resources. In Amos' time, the people had winter and summer houses, houses of ivory and hewn stone houses. In Nigeria, some people have houses in almost every part of the country. While some of these houses are built with ordinary block cement, some are built with baked clay while others are made also of hewn stone. The fleet of cars being paraded in Nigeria is also a sign of this economic prosperity. The interior decoration of these houses and cars simply denote extravagance.

The economic prosperity could also be seen in the extravagant way some Nigerians eat and dress, just like in Amos' time. Amos called only the women of Samaria cows of Bashan (Amos 3:4) because of their extra size, gained through excessive eating and drinking, but here in Nigeria both men and women have this extra size, gained through corruption or ill-gotten wealth. Many Nigerians display a lot of wealth in the way they dress. They usually put on expensive clothes. The expensive jewelries and perfumes they wear speak of affluence. The pair of shoes and wristwatches cannot be left out for they are very costly too. This sign of affluence could also be seen in the way wealthy Nigerians display money during social functions such as wedding, traditional marriage, funeral ceremonies, birthday parties and so on. In the full glare of the public these wealthy ones spray money like water 
on the celebrants. Sometimes bundles of money are sprayed one after the other to the excitement of the masses.

Most unfortunately, the prosperity or wealth of the Nigerian nation, which is confined to few groups of people, has brought with it all kinds of economic hardship, social disintegration and moral decay in Nigeria. In Nigeria, money is the measure for all things because of the inestimable value attached to it; everyone itches to get it through hook or crook. At Amos' time, Amos relates how the businessmen of his time get impatient for the termination of the holy and work free periods of new moon and Sabbath so that they can engage in their corrupt business practices. The same situation is applicable to Nigeria. According to Ugwueye (2001):

Nigerians who are engaged in what may be called the real business of buying, selling and supplying of goods and services for money are the real deceits. They, of course, make the shekel and the ephaph small as Amos said. The cups, tins and bags used in measuring grains are below their sizes and still the grains measured with them are sold at the same price as the ones measured with full sized measures. (p. 54).

The above situations show that traders in Nigeria do not have the interest of the buyers at heart and therefore, they cheat the buyers in order to enrich there own purse. Amos pointed out that the business of his time also sold the refuse of wheat to the people. This is equivalent to the rampant adulteration of goods in Nigeria just to make money. In fact, the rate at which adulterated drugs, fake and poor quality products are produced in Nigerian is very serious worry to the good citizens because these have sent many to their grave. Despite these difficult situations, Nigerian government 
has not been serious in alleviating the problem of injustice in the economic sector of the country.

\section{ii. Socio-Political Injustice}

Just like in Amos' time, the prosperity or wealth of the Nigerian nation, which is confined to some few group of people, has brought with it all kinds of political decay in Nigeria. The quickest way of amassing wealth in Nigeria today is to occupy a political office or position. During elections people who win are not the real winners, but the cleverest riggers. Unemployed youths are paid and used as thugs to manipulate elections. Human life is valued less than political goals just as the poor were equated with a pair of shoes in Amos' time.

Embezzlement of public funds by those in authority has been given the appearance of legality in Nigeria. Schools, roads, hospitals and other social facilities are poorly maintained. The poor masses bear the direct brunt for they are the ones to be hospitalized in the public hospitals where there are no adequate drugs. Their children are the ones to attend the public schools where the teachers are not devoted to their work because of the epileptic payment of salaries. The wealthy ones can afford to pay for the bills in private hospitals and schools. Most times their children attend schools in overseas countries. The poor parents who spend their fortunes to train their children in school cannot reap the benefit of their effort because government cannot provide jobs. It is no longer graduate unemployment, but post-graduate unemployment. Many Masters and PhD degree holders are jobless. Nigeria as a nation is rich but those in authority embezzle and mismanage the wealth to the detriment of the poor masses.

Clearly, the prevalence of injustice in Nigeria is largely traceable to the type of leadership we have been experiencing since 
independence. Many Nigerian leaders have not been able to rise above the situation they met on the ground, because they came into office without just vision or with corrupt vision. Many past Nigerian leaders since independence often thought there was no corruption in Nigerian politics while some others who acknowledged it, for one reason or the other failed to muster adequate forces against it. This is the reason why Achebe (1983) earlier said:

The trouble with Nigeria is simply and squarely a failure of leadership. There is nothing basically wrong with the Nigerian climate or water or air or anything else. The Nigerian problem is the unwillingness or inability of its leaders to rise to the responsibility, to challenge personal example which are the hall marks of true leadership. (p. 4).

It does appear that injustice in Nigeria is part of what are handed over from one government to the other. This is why corruption seems to be institutionalized in Nigeria.

\section{iii. Socio-Religious Injustice}

In spite of all the corruption and immorality in the $8^{\text {th }}$ century Israel, Amos made us know that the people punctiliously observed their religion. The same is true of Nigerians. Despite all the corruption and immorality in Nigerian society, people are pretending to be religious, observing their religious duties as a matter of life and death. This is observable from the life of many Christians and Moslems. Obiora (1998) rightly observes that religion in Nigeria today is being used for selfish ends. He sees religion as a fast business that people are embarking on. Looking at Christianity in Nigeria, the numerous churches in Nigeria today are not born out for pure motive of serving God but for selfaggrandizement. With a close study and interaction, most 
Christians do not know what they believe in, whether money or God. Because they have more concern for their business than God, they always strive after the way to accumulate more wealth for themselves, forgetting the demands of their relationship with God who is the foundation of all beings. They do not even have time for studying God's word. Today, we can hardly distinguish between a Christian and a non-Christian, because of the crave for wealth and pleasure.

Nigeria Christians make regular visits to worship centres. The regularity with which these centres are visited by Christians is alarming. Apart from this, the Christians organize religious crusades everywhere and every time in this country. There was constant performance of rituals at the sanctuaries during Amos' time. Nigerians as well show diligently these external forms of religion without any spiritual commitment. Various sacrifices and tithes, of stolen money, are offered daily in the church. Bribes are offered before one goes on a pilgrimage to Jerusalem. This is committing sin under the cloak of religion.

Religious feasts, which are very many in Christianity, are observed meticulously by Nigerian Christians. Offerings, especially thanksgiving offerings, by those who succeed in their improper business are regularly given in the churches. Amos was talking of the noise of songs and the melody of harps during his own time, today in Nigeria, it is the noise of the musical equipments that is heard in religious centres. Both the offering and the music are all religious formalism and external rites unrelated to interior morality.

\section{iv. Socio-Judicial Injustice}

The rape on justice in Nigeria even by the judiciary which is the last hope for the common man is an open secret. The judiciary is 
the branch of government invested with judicial powers to interpret, construct and apply the law so as to produce justice by discovering the truth. The whole process of adjudication is thus a human attempt at the discovering of truth. It is the end which ought to be reached in a case by the administration of the principles of the law involved as applied to the facts. The court should therefore be a temple of justice.

According to Oputa (1996), "It is a common knowledge that the courts are infested by the virus of bribery and corruption" (p. 6). This has made justice in our courts a marketable commodity with the hammer falling for the highest bidder. Ugwueye (2001) rightly says:

Venal judges and all other people that settle disputes at all levels of the society deny poor people justice, because of bribe from the rich. The rich are constantly claiming poor people's acres of land, yet the court always rules in favour of the rich, because of bribery. (p. 56).

Muojekwu (2006) also clearly states that:

It is very unfortunate that Nigerian courts have turned into war zones by greed, avarice, selfishness, and various unspeakable deeds of judges who prepare two contradictory verdicts (judgements), one for the plaintiff and the other for defendant; these judges wait anxiously to sell the verdict to the highest bidder. (p. 55).

In the light of the above quotations by Ugwueye and Muojekwu, what happens in judicial sector in Nigeria should not surprise any right thinking and honest Nigerian. This is to say that in Nigeria, judiciary as an organ of government is no longer the hope of the common man, rather the grave of common man.

The 'equality before the law' seems to be a statement in mass deceit. Our police cells and prisons are filled with inmates 
whose only crime was that they could not pay their way through the modern criminal justice system. Human rights are abused daily under obnoxious decrees. Political opponents are some times clamped into detention centers in the name of state security. The Nigerian judiciary is indeed lousy with corrupt institution as some alleged miscreants rot in cells and prisons in the name of awaiting trial. Justice delayed is justice denied. The biblical assertion that the love of money is the source of all evils cannot be overemphasized. In our world today one is constantly told that there is nothing money cannot buy from life. This follows that money can buy justice.

\section{Relevance of Amos' Message to Development in Nigeria}

Amos' message of social justice to the Israelites of his time teaches Nigerians a lot of lessons, which can positively affect the life of the nation today. Development is not something that can be achieved by science and technology alone. Development can be human oriented because man is body and soul and both can be developed. Amos emphasizes the importance of social justice in human society. Therefore, development cannot be achieved without a concerted effort at good moral and spiritual human living within the society. It means using the things that God has created to improve the lives of all people according to the will of God. Nigerians are known for being religious. Being religious which implies being in a covenant relationship with God means that we must be righteous and our behaviour must reflect the fact that we are God's people.

Since God is just, righteous and loving, Nigerians should learn to demonstrate these virtues in relationship and dealing with our fellow human beings for the sustenance of development in the Nigeria. We may ask ourselves if we expect God to share our 
allegiance to him as religious people with some equivalent of 'religiosity without religion' as the Israelites did. We may worship God in theory, but in practice place our selfish priority in money, business, fame, politics, charms, secret cults, etc. If any of these things or anything else, replaces God or even is placed more important, then we are not better than Israelites of Amos' time.

Our understanding of Amos' critique of social injustice is bound to affect our relationships with our fellow human beings. Amos sees justice and ethical conduct as the foundation of society. He maintains that worship by a people whose lives are characterized by selfishness, greed, immorality and oppression is an abomination to God. Many Nigerians practise religion as a matter of life and death without spiritual attachment. Prophet Amos was God's messenger who insisted that if the Israelites would like to maintain a relationship of love with him they had to make sure that they treated their fellow Israelites like covenanted sisters and brothers. For him, injustice and oppression in the society is not a mere evil but sin. Accordingly, it is not worship or religious matters that occupy an important place and more space but rather social justice, love and concern for the poor, the underprivileged, the marginalized, and sincerity in one's dealings with the neighbour (cf. Exodus 20:22-23:33). In the same manner, Nigerians should be just in relating with one another bearing in mind that they are members of the same nation.

This clarion call to social justice by Amos is a challenge to Christianity, Islam and African traditional religion, three major religions professed by the Nigerian population. The problems and prospects of our socio-religious realities touch on the tenets of these religions. The underprivileged and the downtrodden in our villages and city slums are Nigerians and adherents of these faiths. At the same time the oppressors who collude with trans-national 
corporation to exploit Nigerians, the pen-robbers in the banks and financial institutions and the fraudulent men and women in our establishments are people who claim allegiance to either religion. To combat social injustice and wrong-doing in our contemporary society is a task to be religiously pursued by Christianity, Islam and African traditional religion. Adherents of these religions must come to recognize the need for dialogue and collaboration. This move must be practically evident in our behaviour for national development.

\section{Conclusion}

The road to national development in Nigeria must be paved with social justice. As discussed in this paper, Amos' critique of social injustice in $8^{\text {th }}$ century Israel is relevant to contemporary Nigerian society owing to the fact that social injustices that occurred in Israel at Amos' time are also observed in Nigeria today. There will be no meaningful development in Nigeria when there are injustices virtually in all the sectors of the country. Unless Nigerian nation undergoes serious administrative and behavioural changes, the country shall remain permanently underdeveloped. Every human person is entitled to justice irrespective of position and social status. Nigerians should internalize the message of Amos on social justice by discouraging injustice for where there is justice there is peace and development.

Ikenna L. Umeanolue

Department of Religion \& Human Relations

Nnamdi Azikiwe University, Awka

il.umeanolue@unizik.edu.ng 


\section{References}

Achebe, C. (1983). The trouble with Nigeria. Enugu. Fourth Dimension.

Adrian-Vallance et al (Eds.) (2009). Longman dictionary of contemporary English. Edinburgh: Pearson.

Barré, M. L. (1995). Amos. In R. E. Brown, J. A. Fitzmyer and R.

E. Murphey (Eds.). The new Jerome biblical commentary (pp. 209-216). London: Burns and Dates.

Ceresko, A.R. (1992). The Old testament: A liberation perspective. Bangalore: St Paul.

Drane, J. (1987). Introducing the Old Testament. San Francisco: Harper \& Row.

Emenike, H. O. (2003). Bible history: An introduction. Umuahia: Prince International.

Horny, A. S. (Ed.) (2000). Oxford advanced learners dictionary of current English. London: Oxford University.

Iwe, N. S. S. (1985). Christianity, culture and colonialism in Africa. Port Harcourt: Department of Religious Studies, College of Education.

Johnson, A. G. (2002), The dictionary of sociology. Black Hall Britain Building.

MacDonald, W. (1990). Amos. In A. Farstad (Ed.). Believer's Bible commentary (pp. 1113-1120). Mexico: Thomas Nelson.

Menezes, R. (2003). The Old Testament for our times. Bandra, Mumbai: St Paul.

Muogbo, N. (2003). Introduction to sociology. Enugu: Strong Tower.

Obiora, F. (1998). The divine deceit: Business in religion. Enugu:

Optimal. 
Obiajulu, A. O. (1996). Norms, values, moral obligations and social justice in Nigeria: A sociological analysis in contemporary issues. Owerri: Ark.

Oputa, C. (1996). The application of the four way test in the judiciary. Lecture delivered during the Rotary District 9140 Conference $10^{\text {th }}$ May, 1996.

Orjiakor, N. \& Unachukwu, G. C. (2001). Nigerian socio-political development: Issues and problems. Enugu: John Jacob's Classic.

Otite, O. E. (1978). An introduction to sociological Studies. Ibadan: Heinemann.

Slight, G. (1986). The supreme court as an instrument of social justice. Sterling: New Delhi.

Thorogood, B. (1992). A guide to Amos. London: SPCK.

Ugwueye, L. E. (2002). Prophets and prophecy in the Old Testament. Nsukka: Prize.

Vander, Z. Y. W. (1988). The social experience: An introduction to sociology. New York: Randon House. 